\title{
Mengembangkan Kemampuan Motorik Halus Anak Usia Dini melalui Kegiatan Menggunting Dan Menempel Gambar di PAUD Bungong Seuleupok Universitas Syiah Kuala
}

\author{
Rosmiati $^{1}$, Erna Sasmita ${ }^{2}$, Yuhasriati ${ }^{3}$ \\ PG-AUD FKIP Unsyiah ${ }^{1}$ \\ PAUD Bungong Seuleupok ${ }^{2}$ \\ PG-AUD FKIP Unsyiah \\ rosmiati@unsyiah.ac.id ${ }^{1}$ \\ erna19801028@gmail.com \\ yuhasriati@unsyiah.ac.id \\ DOI : $10.32672 /$ jsa.v7i5.1510
}

\begin{abstract}
ABSTRAK
Penelitian ini dilakukan untuk mengembangkan kemampuan motorik halus anak usia dini melalui kegiatan menggunting dan menempel gambar. Sebanyak 21 orang anak di kelas B1 PAUD Bungong Seuleupok Universitas Syiah Kuala dipilih sebagai subjek dalam Penelitian Tidakan Kelas ini. Penelitian dilakukan dalam dua siklus dimana setiap siklus meliputi tahap perencanaan, pelaksanaan, pengamatan, dan refleksi. Teknik pengumpulan data berupa observasi, wawancara dan unjuk kerja anak. Data penelitian dianalisis secara deskriptif kualitatif melalui tahapan pengumpulan data, reduksi data, penyajian data dan penarikan kesimpulan. Hasil penelitian menunjukan bahwa adanya perkembangan kemampuan motorik halus anak usia dini setelah dilakukan tindakan melalui kegiatan menggunting dan menempel gambar. Berdasarkan hasil tindakan Siklus I dan Siklus II, maka dapat disimpulkan bahwa kegiatan menggunting dan menempel gambar dapat mengembangkan kemampuan motorik halus anak usia dini.
\end{abstract}

Kata Kunci: Motorik Halus, Menggunting dan Menempel Gambar

\section{PENDAHULUAN}

Pendidikan anak usia dini sedang mendapatkan perhatian serius terutama dari pemerintah, karena disadari benar bahwa anak akan menjadi generasi penerus di masa mendatang. Untuk mewujudkan generasi penerus yang tangguh dan mampu berkompetensi diperlukan upaya pengembangan anak sesuai dengan masa pertumbuhan dan perkembangannya. Undang-undang Republik Indonesia Nomor 20 tahun 2003 tentang Sistem Pendidikan Nasional bab 1, pasal 1, butir 14, menetapkan bahwa pendidikan anak usia dini adalah suatu upaya pembinaan yang ditujukan kepada anak sejak lahir sampai dengan usia enam tahun yang dilakukan melalui pemberian rangsangan pendidikan untuk membantu pertumbuhan dan perkembangan jasmani dan rohani agar anak memiliki kesiapan dalam memasuki pendidikan lebih lanjut (Cossio et al., 2012). 
Pendidikan anak usia dini merupakan pendidikan yang paling mendasar dan menempati kedudukan sebagai masa emas (golden age) dan sangat strategis dalam pengembangan sumber daya manusia (Yamin, 2010 :1). Usia lahir sampai usia enam tahun merupakan masa peka bagi anak, dimana anak mulai sensitif untuk menerima berbagai upaya pengembangan seluruh potensi yang dimiliki. Masa peka adalah masa terjadinya pematangan fungsi-fungsi fisik dan psikis yang siap merespon stimulus yang diberikan oleh lingkungan. Pada masa ini merupakan masa untuk meletakkan dasar pertama dalam mengembangkan kemampuan fisik motorik, kognitif, bahasa, sosial-emosional, konsep diri, disiplin, kemandirian, seni, moral dan nilai-nilai agama.

Perkembangan fisik motorik terutama motorik halus anak usia dini harus mendapat perhatian dengan pelaksanaan pembelajaran yang direncanakan secara matang agar siap memasuki pendidikan selanjutnya. Proses pembelajaran hendaknya dapat membantu anak untuk mengeksplorasi, mengamati, memperlihatkan dan mengembangkan imajinasi dan kreativitasnya. Maka untuk itu layanan pendidikan anak usia dini harus menyediakan berbagai kegiatan pembelajaran yang menyenangkan (Yuhasriati \& Yuriansa, 2018), dan menstimulasi fisik motorik terutama motorik halus anak usia dini. Berbagai kegiatan pembelajaran seperti menempel, mengunting dan melipat kertas dapat mengembangkan kemampuan motorik halus pada anak (Fitriani, 2019; Suyanto, 2005:51).

Kegiatan menggunting dan menempel dapat digunakan untuk mengembangkan kemampuan motorik halus pada anak usia dini. Mengembangkan motorik halus anak usia dini dapat dilakukan dengan berbagai kegiatan. Motorik halus dikembangkan tidak hanya dengan kegiatan membaca, menulis dan berhitung sebagaimana yang dilakukan pada proses pembelajaran model lama. Supaya anak usia dini belajar lebih menyenangkan, sekolah menyediakan berbagai fasilitas sebagai media untuk kegiatan anak bermain yang dapat mengembangkan motorik halus.

Salah satu aspek yang penting untuk dikembangkan adalah aspek perkembangan kemampuan motorik halus. Syaodih (2005:31) menyatakan bahwa berbagai kemampuan yang dimiliki anak dalam menggunakan otot-otot fisiknya baik motorik halus maupun motorik kasar dapat menimbulkan rasa percaya diri pada anak karena anak mampu menguasai keterampilan-keterampilan motorik. Selanjutnya Hurlock (1978:158) mengemukakan bahwa keterampilan motorik tidak akan berkembang melalui kematangan saja melainkan keterampilan itu harus dipelajari.

Peraturan Menteri Pendidikan dan Kebudayaan Nomor 137 Tahun 2014 menetapkan bahwa tingkat pencapaian perkembangan motorik halus anak usia 4-5 tahun sudah mampu membuat garis vertikal, horizontal, lengkung kiri/kanan, miring kiri/kanan dan lingkaran; menjiplak bentuk; mengkoordinasikan mata dan tangan untuk melakukan gerakan yang rumit; melakukan gerakan manipulatif untuk menghasilkan suatu bentuk dengan menggunakan berbagai media; mengekspresikan diri dengan berkarya seni menggunakan berbagai media dan mengontrol gerakan tangan yang menggunakan otot halus (menjumput, mengelus, mencolek, mengepal, memelintir, memilin, memeras).

Hasil observasi awal yang dilakukan di Kelas B1 PAUD Bungong Seuleupok Universitas Syiah Kuala menunjukkan bahwa masih ada anak yang belum mampu untuk memegang pensil dan gunting dengan baik. Anak masih terlihat kaku ketika menyambungkan huruf. Anak masih terlihat belum mampu menggerakkan jari-jari tangan 
dengan benar. Peneliti melihat jari-jari tangan anak masih belum leluasa digerakkan. Pada kegiatan mewarnai dan menyusun huruf, terlihat jari-jari tangan masih kaku ketika menggerakkan krayon.

Berdasarkan dari latar belakang di atas, masalah yang menjadi fokus dalam penelitian ini adalah bagaimana mengembangkan kemampuan motorik halus anak melalui kegiatan menggunting dan menempel gambar di Kelas B1PAUD Bungong Seuleupok Universitas Syiah Kuala.

\section{METODE PENELITIAN}

Penelitian ini menggunakan rancangan Penelitian Tindakan Kelas (PTK). Model PTK yang digunakan adalah model penelitian tindakan kelas yang dikembangkan oleh Kemmis dan Tegart (Arikunto, 2012:74) yang setiap siklus terdiri atas perencanaan, pelaksanaan, pengamatan, dan refleksi.

Subjek penelitian adalah anak usia 5 sampai 6 tahun di kelas B1 PAUD Bungong Seuleupok Universitas Syiah Kuala yang berjumlah 21 orang anak. Teknik pengumpulan data dilakukan dengan teknik observasi dan wawancara. Observasi adalah pengamatan secara langsung yang dilakukan oleh peneliti terhadap sumber yang diteliti, sedangkan wawancara adalah interaksi antara peneliti dengan guru dan anak dengan memberikan beberapa pertanyaan dengan cara mencatat atau merekam.Penelitian tindakan kelas ini dilaksanakan selama 10 kali pertemuanpembelajaran pada semester genap tahun ajaran 2018/2019 yang dimulai dari bulan Agustus hingga bulan September 2018.

Instrumen yang digunakan dalam penelitian ini meliputi format penilaian pelaksanaan kegiatan menggunting dan menempel gambar yang digunakan peneliti untuk mengetahui perkembangan motorik halus anak.Teknik analisis data penelitian tindakan kelas ini dilakukan secara deskriptif kualitatif. Analisis data menggunakan bintang satu sampai bintang empat. Bintang satu untuk kategori Belum Berkembang (BB) yaitu anak melakukan kegiatan menggunting dan menempel gambar dengan bantuan guru sepenuhnya. Bintang dua untuk kategori Mulai Berkembang (MB) dimana anak melakukan kegiatan menggunting dan menempel gambar dengan sedikit bantuan guru. Bintang tiga untuk kategori Berkembang Sesuai Harapan (BSH) yaitu anak mampu menggunting dan menempel gambar secara mandiri, namun hasilnya tidak sempurna. Bintang empat diberikan untuk kategori Berkembang Sangat Baik (BSB) dimana anak mampu menggunting dan menempel gambar secara mandiri dan hasilnya sempurna.

Penelitian ini akan dikatakan berhasil apabila kemampuan anak dalam menggunting dan menempel gambar mencapai $75-80 \%$ dengan mendapatkan kriteria Berkembang Sesuai Harapan (BSH) atau bintang tigadan mendapatkan kriteria Berkembang Sangat Baik (BSB) atau bintang empat sebagaimana dinyatakan oleh Sudjana (Dimyati 2013:105) bahwa batas ketuntasan secara klasikal dari hasil belajar anak adalah $75-80 \%$. Berdasarkan pendapat di atas peneliti menggunakan acuan tersebut untuk melihat keberhasilan dari penelitian ini. 
Rosmiati, Erna Sasmita, Yuhasriati

\section{HASIL DAN PEMBAHASAN}

Keterampilan motorik halus merupakan keterampilan yang memerlukan kemampuan untuk mengontrol otot-otot kecil. Keterampilan ini melibatkan koordinasi neuromuscular (syaraf otot) yang memerlukan ketepatan derajat tinggi untuk berhasilnya keterampilan ini. Keterampilan jenis ini sering disebut sebagai keterampilan yang memerlukan koordinasi mata-tangan. Menulis, menggambar, bermain piano adalah contoh-contoh keterampilan tersebut.

Berdasarkan hasil diskusi dan pengamatan awal yang telah dilakukan, peneliti beserta tim kolaborasi menentukan jadwal pelaksanaan tindakan Siklus I sesuai dengan perencanaan yang telah dituangkan dalam bentuk Rencana Pelaksanaan Pembelajaran Mingguan dan Rencana Pelaksanaan Pembelajaran Harian. Tim kolaborasi melakukanpengamatan pada saat tindakan Siklus I dilaksanakan. Pengamatan dilakukan terkait dengan kemampuan anak dalam menggunting dan menempel gambar untuk melihat perkembangan motorik halus dalam bentuk ceklist pada lembar observasi.

Berdasarkan hasil penelitian, dapat dilihat pengembangan kemampuan motorik halus anak melalui kegiatan menggunting dan menempel gambar di kelas B1 PAUD Bungong Seuleupok Universitas Syiah Kuala. Perkembangan tersebut sangat jelas terlihat dengan adanya perbedaan pada pelaksanaan tindakan Siklus I dan Siklus II. Perbedaan ini dapat dilihat dari setiap kegiatan yang dilakukan anak pada saat kegiatan menggunting dan menempel gambar. Kemampuan motorik halus melalui kegiatan menggunting dan menempel gambar dapat melatih jari-jari tangan anak sehingga mudah digerakkan dengan baik.

Tabel 1. Rekapitulasi Hasil Tindakan Siklus I dan Siklus II

\begin{tabular}{|c|c|c|c|c|c|}
\hline \multirow[t]{3}{*}{ No } & \multirow[t]{3}{*}{ Kriteria Penilaian } & \multicolumn{2}{|c|}{ Tindakan Siklus I } & \multicolumn{2}{|c|}{ Tindakan Siklus II } \\
\hline & & Jumlah & Persentase & Jumlah & Persentase \\
\hline & & Anak & & Anak & \\
\hline 1 & Belum Berkembang & 10 & 47,62 & 0 & 0 \\
\hline 2 & Mulai Berkembang & 6 & 28,58 & 4 & 19,04 \\
\hline 3 & $\begin{array}{l}\text { Berkembang Sesuai } \\
\text { Harapan }\end{array}$ & 5 & 23,80 & 10 & 47,62 \\
\hline 4 & $\begin{array}{l}\text { Berkembang Sangat } \\
\text { Baik }\end{array}$ & 0 & 0 & 7 & 33,34 \\
\hline
\end{tabular}

Hasil tindakan pada Siklus I menunjukan bahwa perkembangan motorik halus anak melalui kegiatan menggunting dan menempel gambar belum mencapai kriteria ketuntasan yang telah ditetapkan. Pada kategori Belum Berkembang (BB) terdapat 10 orang anak dengan persentase sebanyak 47,62 \%. Kategori Mulai Berkembang (MB) sebanyak 6 orang anak dengan persentase sebesar 28,58 \%. Pada kategori Berkembang Sesuai 566 
Harapan (BSH) hanya terdapat 5 orang anak dengan persentase sebesar 23,80\%, sedangkan pada kategori Berkembang Sangat Baik (BSB) belum ada anak yang mampu mencapai kriteria ini.

Pada hasil refleksi Siklus I ditemukan beberapa permasalahan dan kendala yang dihadapi anak dalam menggunting dan menempel gambar seperti anak masih sulit untuk memegang gunting dengan benar dan mengoles lem sesuai dengan ukuran gambar. Hasil refleksi tindakan Siklus I dijadikan pedoman dalam perencanaan tindakan Siklus II agar tindakan yang dilakukan dapat mengembangkan kemampuan motorik halus anak. Perbaikan yang dilakukan peneliti dan tim kolaborator meliputi Rencana Pelaksanaan Pembelajaran, media pembelajaran dan strategi pembelajaran.

Tabel 1 tentang rekapitulasi hasil tindakan Siklus I dan II menunjukan bahwa pada Siklus II hasil tindakan telah mencapai indikator kenerja yang telah ditetapkan, yaitu sebanyak 75-80\% dimana hasil tindakan Siklus II mencapai 80,96 \% pada kategori Berkembang Sesuai Harapan (BSH) dan Berkembang Sangat Baik (BSB). Kategori Belum Berkembang (BB) tidak terdapat lagi anak yang kemampuan motorik halusnyapada tingkatan paling rendah. Pada kategori Mulai Berkembang (MB) terdapat 4 orang anak dengan persentase sebesar 19,04\%. Kategori Berkembang Sesuai Harapan (BSH) terdapat 10 orang anak dengan persentase sebesar 47,62\% dan pada kategori Berkembang Sangat Baik (BSB) adalah sejumlah 7 orang anak atau dengan perolehan pencapaian sebesar 33,34\%. Dikarenakan hasil tindakan pada Siklus II telah memenuhi indikator kinerja yang telah ditetapkan dalam penelitian tindakan kelas ini, maka peneliti menghentikan penelitian hanya sampai pada Siklus II dan tidak dilanjutkan ke Siklus III.

\section{PENUTUP \\ Simpulan}

Berdasarkan hasil tindakan Siklus I dan Siklus II, maka dapat disimpulkan bahwa kegiatan menggunting dan menempel gambar dapat mengembangkan kemampuan motorik halus anak usia dini.

\section{Ucapan Terima Kasih}

Penelitian tindakan kelas ini terlaksana berkat dukungan dan kepercayaan yang telah diberikan kepada peneliti oleh Dekan FKIP Unsyiah dan seluruh jajarannya. Terimakasih kepada Dekan FKIP Unsyiah atas semua kemudahan dan dukungan yang telah diberikan. Terimakasih juga Kepala Lembaga PAUD Bungong Seuleupok Universitas Syiah Kuala, tim kolaborator dan seluruh dewan guru yang telah membantu peneliti dalam menyelesaikan penelitian ini.

\section{DAFTAR PUSTAKA}

Arikunto, Suharismi., dan Suhardjono. 2012. Penelitian Tindakan Kelas. Jakarta: PT. Bumi Aksara.

Cossio, M. L. T., Giesen, L. F., Araya, G., Pérez-Cotapos, M. L. S., Vergara, R. L., 
Rosmiati, Erna Sasmita, Yuhasriati

Manca, M., ... Héritier, F. (2012). Undang-Undang Republik Indonesia Nomor 20

Tahun 2003 Tentang Sistem Pendidikan Nasional. Uma Ética Para Quantos? https://doi.org/10.1007/s13398-014-0173-7.2

Dimyati, Johni. 2013. Metodologi Penelitian dan Aplikasinya pada Pendidikan Anak Usia Dini. Jakarta: Kencana Prenatal Media Group.

Fitriani, Ridhwan, M. (2019). Meningkatkan Ketrampilan Motorik Halus Anak dengan Kegiatan Origami TK Pertiwi Kota Banda Aceh. Availiable at: http://www.ojs.serambimekkah.ac.id/index.php/serambi-ptk/article/view/1133

Hurlock, E.B. 1978. Perkembangan Anak Jilid 1. (Alih Bahasa: Meitasari Tjandra \& Muslichah Zarkasih). Jakarta: Erlangga.

Suyanto, Slamet. 2005. Konsep Dasar Pendidikan Anak Usia Dini. Jakarta: Departemen Pendidikan Nasional.

Syaodih, Ernawulan. 2005. Bimbingan di Taman Kanak-Kanak. Jakarta: Departemen Pendidikan Nasional.

Yamin, Martinis dan Sabri, Sanan. 2010. Panduan Pendidikan Anak Usia Dini. Jakarta: Gung Persada (GP) Press.

Yuhasriati, Y., \& Yuriansa, A. (2018). Patterns playing for early childhood education: Mathematics learning for early childhood education. In Journal of Physics: Conference Series. https://doi.org/10.1088/1742-6596/1088/1/012099 